\title{
SI GARANG (STIK IKAN PRINGGAJURANG) SEBAGAI UPAYA MENINGKATKAN NILAI EKONOMI HASIL PRODUKSI IKAN DI DESA PRINGGAJURANG KECAMATAN MONTONG GADING KABUPATEN LOMBOK TIMUR
}

\author{
Juhaeri'ah1, Maulida Rizka Mardiyanti2, Nurul Maulidina3, I Wayan Wariata4 \\ 1Pendidikan Biologi, Fakultas Keguruan Dan Ilmu Pendidikan, Universitas Mataram, Mataram \\ 2Pendidikan Guru Sekolah Dasar, FKIP, Universitas Mataram, Mataram \\ 3Teknik Pertanian, Fakultas Teknologi Pangan dan Agroindustri, Universitas Mataram, Mataram \\ 4Peternakan, Fakultas Peternakan, Universitas Mataram, Mataram \\ ${ }^{*}$ Co-Author : jjuhaeriah94@gmail.com
}

\begin{abstract}
ABSTRAK. Tulisan ini menjelaskan tentang upaya yang dilakukan untuk meningkatkan kualitas sumber daya masyarakat desa Pringgajurang serta sumber daya alam yang dimiliki melalui pelatihan dan pengolahan ikan menjadi stik ikan. Desa Pringgajurang merupakan desa yang aktif berkerjasama dengan BUMDes Al-ikhlas yang merupakan badan usaha desa yang ikut serta dalam mengembangkan potensi desa dan pengelolaan usaha masyarakat desa Pringgajurang. Hal tersebut telah didukung dengan ketersediaan perlengkapan yang dibutuhkan masyarakat terkait dengan pengembangan usaha masyarakat. Namun, yang menjadi kendala didesa ini ialah kurangnya pengetahuan masyarakat dalam hal cara pengolahan ikan untuk menjadi produk yang diinginkan. Sehingga pelatihan mengenai pembuatan stik ikan dalam rangka memberikan pembelajaran kepada masyarakat agar dapat mengelola ikan untuk meningkatkan nilai jual dari ikan yang melimpah pada musim-musim tertentu dapat dilakukan. Dampak yang ingin dicapai ialah terciptanya masyarakat yang mampu mengelola sumber daya yang ada didesa tersebut. Metode pengumpulan data yang digunakan adalah observasi dan wawancara sedangkan metode analisis menggunakan deskriptif kualitatif. Hasil yang telah dicapai dengan adanya program ini ialah bertambahnya pengetahuan masyarakat untuk mengoptimalkan sumber daya ikan sehingga terciptanya produk olahan stik ikan yang berkualitas dan berdaya saing dipasaran..
\end{abstract}

Kata Kunci: Sumber daya, Ikan, Stik ikan

ABSTRACT. This article describes the efforts made to improve the quality of community resources in the village of Pringgajurang and the natural resources provided through training and processing fish into fish. Pringgajurang Village is an active village in collaboration with BUMDes Al-ikhlas which is a village business entity that participates in developing village potentials and managing the business activities of Pringgajurang village communities. This must be supported by supported equipment needed by the community related to community business development. However, the challenge in this village is to increase public knowledge in terms of processing fish to become the desired product. Conduct training on how to make fish in the framework of providing learning to the community so that they can make fish to increase the selling value of abundant fish in certain seasons. The desired impact is the successful creation of a community capable of managing the resources in the village. Data collection methods used were observation and interviews while the analytical method used descriptive qualitative. The results that have been obtained with this program are 
increasing public knowledge to increase fish resources so that the creation of quality processed fish products and competitive in the market..

Keyword: Resources, Fish, Fish Sticks

\section{PENDAHULUAN}

Desa Pringgajurang merupakan salah satu desa yang ada di kecamatan Montong Gading Kabupaten Lombok Timur. Desa Pringgajurang dihuni oleh masyarakat dengan mayoritas pekerjaan sebagai petani dan peternak ikan. Jumlah penduduk desa PringgaJurang pada tahun 2020 sebanyak laki-laki 2103 jiwa dan perempuan sebanyak 1915 jiwa. Luas wilayah desa PringgaJurang 265,89 Ha. Desa PringgaJurang terdiri dari 6 dusun yaitu dusun Pengembur, Dusun Dasan Baru, Dusun Dalam Desa Utara, Dusun Dalam Desa Selatan, Dusun Kayu liyan, dan Dusun Temiling. Potensi unggulan desa Pringgajurang bergerak pada bidang pertanian dan peternakan secara luas terutama hasil pertanian berupa padi, jagung, dll sedangkan hasil peternakan berupa ikan nila.

Ikan merupakan sumber protein yang cukup tinggi dan sangat penting untuk pertumbuhan (Pratiwi, 2013). Ikan nila termasuk komoditas yang banyak dibudidaya didesa Pringgajurang. Menurut Yanuar, dkk (2016) Dewasa ini, produk olahan sudah banyak dikembangkan dengan menggunakaan bahan dasar ikan mulai dari jelly fish product sampai makanan kering seperti seperti stik ikan. Menurut Putri, dkk (2018) Ikan nila merupakan salah satu jenis ikan yang memiliki permintaan pasar yang cukup tinggi, rasa dagingnya yang enak, harga yang relatif stabil serta pemeliharaannya yang mudah. Protein dalam tubuh ikan merupakan senyawa yang kandungannya paling tinggi setelah air. Protein memegang peranan penting dalam struktur dan fungsi tubuh, seperti pertumbuhan dan reproduksi. Menurut Utami (2018) Ikan dapat menarik minat konsumen khususnya yang tidak terlalu gemar makan ikan sendiri tetapi disajikan dalam bentuk olahan yang menarik dan salah satunya dijadikan dalam bentuk stik.

Saat ini yang menjadi fokus utama desa Pringgajurang adalah hasil petanian, sehingga potensi yang didapat dari hasil peternakan ikan belum bisa dikembangkan dengan baik. Kebanyakan masyarakat hanya memperjual belikan ikan yang masih segar kepada pembeli yang selanjutnya dijual kembali dipasaran. Oleh karena itu, untuk membantu masyarakat mengembangkan potensi tersebut, hasil peternakan ikan dapat diolah menjadi beranekaragam makanan. Namun, yang menjadi permasalahan utama dalam pengolahan ikan ini ialah masih kurangnya kualitas sumber daya manusia yang tertarik dalam mengolah ikan, hal tersebut dikarenakan kurangnya wawasan masyarakat dalam memanfaatkan ikan menjadi produk olahan yang bernilai jual tinggi.

Melihat potensi yang ada didesa Pringgajurang berupa banyaknya ketersediaan ikan. Kelompok kuliah kerja nyata mengajukan beberapa program kerja untuk membantu mengatasi permasalahan tersebut seperti pengolahan ikan menjadi stik ikan (SI GARANG) sebagai upaya meningkatkan nilai ekonomi hasil produksi ikan didesa Pringgajurang. Program yang diajukan disusun dengan mempertimbangkan faktor-faktor yang mendukung pengolahan setelah melalui observasi dan wawancara dengan masyarakat setempat. Menurut Widjaja dalam Widiastuti (2018) Pemberdayaan potensi masyarakat merupakan suatu upaya meningkatkan kemampuan dan potensi yang dimiliki masyarakat sehingga masyarakat dapat mewujudkan jati diri, bakat dan martabat secara maksimal dan mandiri baik dibidang ekonomi, sosial, agama dan budaya. Pemberdayaan masyarakat dilakukan dengan memberikan pelatihan dan pendampingan 
(Panggabean, 2004). Kegiatan pelatihan dilakukan dengan membuat inovasi olahan ikan menjadi stik ikan.

Stik ikan merupakan salah satu makanan ringan atau jenis kue kering dengan bahan dasar tepung terigu, tepung tapioka atau tepung sagu, lemak telur serta air, yang berbentuk pipih panjang dan cara pemasakannya dengan cara digoreng, mempunyai rasa gurih serta bertekstur renyah (Pratiwi, 2013). Stik ikan dapat dikatakan sebagai makanan kudapan sumber protein hewani karena dibuat dengan bahan baku daging ikan (Salaman, dkk, 2015). Penambahan bahan ikan dalam produk stik dimaksudkan untuk menambah nilai gizi bagi cemilan stik (Siswanti, dkk, 2017).

Melalui program yang kami usulkan diharapkan dapat menambah keterampilan masyarakat untuk mengolah ikan terlebih lagi ketika masa panen ikan. Pada masa-masa tersebut, harga jual ikan biasanya sangat murah (anjlok), dengan melimpahnya ikan dipasaran menyebabkan banyaknya ikan yang terbuang sia-sia karena busuk dan otomatis menyebabkan penjual ikan menjadi rugi. Oleh karena itu, stik ikan (SI GARANG) dapat menjadi salah satu alternatif yang dapat dikembangkan sebagai usaha sampingan masyarakat. Pengolahan diharapkan dapat meningkatkan nilai tambah ikan tersebut sehingga dapat meningkatkan taraf perekonomian masyarakat desa Pringgajurang.

\section{METODE PELAKSANAAN}

Kegiatan dilakukan selama 3 minggu yakni mulai tanggal 5-19 Januari di Desa Pringgajurang, Kecamatan Montong Gading, Kabupaten Lombok Timur, NTB.

\section{Alat Dan Bahan}

Alat yang digunakan dalam program dalam pelatihan pembuatan stik ikan adalah kompor, pisau, cobek dan ulekan, wajan, penggorengan, cetakan, wadah, dan tirisan. Sedangkan bahan yang digunakan adalah daging $1 \mathrm{~kg}$ ikan nila, 500 gram tepung beras (rose brand), 30 gram tepung tapioka atau kanji, 2 sendok blueband, 3 siung bawang putih, 3 siung bawang merah, 3 butir telur, fungsi telur dalam pembuatan stik ialah untuk meningkatkan nilai gizi, rasa serta bersifat sebagai emulsifier dan mengikat komponen-komponen adonan (Irmansyah dan Kusnadi, 2009), 1 bungkus merica bubuk, peyedap rasa, garam, gula, air dan minyak secukupnya untuk digoreng, terdapat bahan tambahan berupa 3 lembar daun seledri.

\section{Prosedur Kerja Dan Program Pelatihan Stik Ikan Pringgajurang}

Prosedur kerja dalam pembuatan stik ikan adalah pertama tama dibersihkan ikan nila, kemudian ikan dikukus sampai empuk. Selanjutnya ikan dipisahkan dari tulang dan ikan dihaluskan menggunakan cobek. Kemudian pembuatan adonan, pembuatan adonan stik dilakukan dengan mencampurkan bahan utama dan bahan-bahan tambahan yang diaduk secara merata, lalu diaduk dengan tangan sehingga dihasilkan adonan yang homogen (Koswara dalam Muzakki (2015)). Adapun adonan dilakukan dengan mencampurkan tepung beras rose brand, tepung tapioka, telur, blueband, bawang putih dan bawang merah yang telah dihaluskan, seledri yang telah di potongpotong kecil, kemudian diaduk merata dan di tambahkan penyedap rasa. Langkah selanjutnya mencetak adonan dengan cetakan manual kemudian digoreng dengan minyak panas adonan yang telah di cetak. Setelah stik ikan berwarna kuning kecoklatan diangkat stik lalu ditiriskan kemudian di kemas. Adapun Program pelatihan stik ikan Pringgajurang terdiri dari 1) 
Mempersiapkan alat dan bahan, 2) Pembukaan kegiatan pelatihan, 3) Pelatihan pembuatan stik ikan, pengemasan dan pemasaran, 4) Evaluasi kegiatan

\section{Bentuk Kegiatan}

Bentuk kegiatan secara keseluruhan ini adalah 1) Persiapan program, 2) Persiapan alat dan bahan, 3) Pembukaan kegiatan, 4) Pelatihan pembuatan stik ikan, pengemasan, dan pemasaran, 5) Produksi tahapan kedua.

\section{HASIL DAN PEMBAHASAN}

Program ini telah dilaksanakan secara terstruktur dengan melibatkan masyarakat secara aktif.

\section{Pelaksanaan Pelatihan Pembuatan Stik Ikan Pringgajurang}

Program pelatihan pembuatan stik ikan dimulai dengan mempersiapkan program yang terdiri dari observasi, wawancara, dan pembersihan lokasi serta alat. Proses wawancara dilakukan dengan pihak kepala desa Pringgajurang dengan tujuan untuk mengetahui potensi yang dimiliki oleh desa serta proses pemberdayaan apa saja yang telah dilakukan oleh masyarakat setempat untuk mengoptimalkan potensi tersebut.

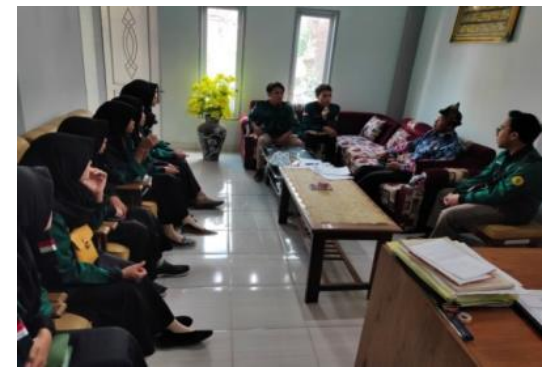

Gambar 1. Wawancara dengan kepala desa Pringgajurang terkait potensi desa

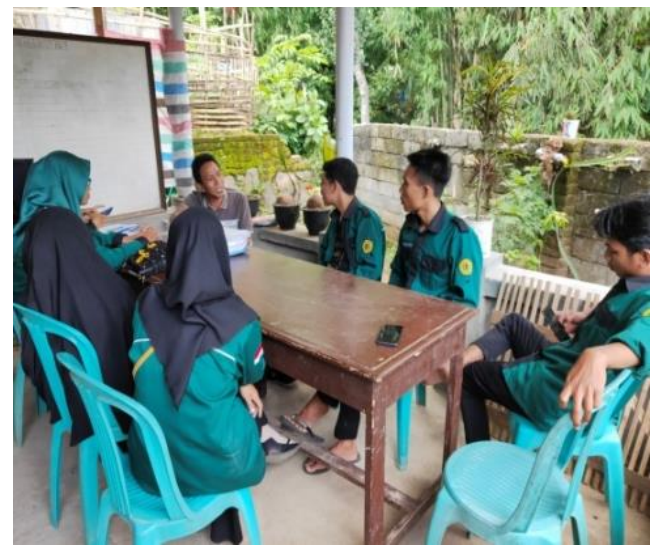

Gambar 2. Wawancara dengan kepala dusun Pengembur desa PringgaJurang terkait potensi desa

Berdasarkan pada hasil wawancara dan observasi terdapat beberapa hal yang ditemukan terkait potensi desa antaranya yaitu hasil pertanian, perkebunan, pembuatan batu bata, dan budidaya ikan. Sebagian besar masyarakat memiliki tempat budidaya ikan yang disebut dengan 
embung/empang yang letaknya di sekitar perumahan, dan terdapat juga kelompok usaha bersama dalam pengrajinan sampah plastik menjadi tas. Selain itu, didesa PringgaJurang memiliki BUMDes yang berperan mengelola dan membangun potensi yang ada didesa. BUMDes berkerjasama dengan masyarakat untuk mengoptimalkan potensi dan menciptakan suatu produk untuk meningkatkan pendapatan desa.

Selanjutnya pada persiapan program ialah pembersihan lokasi dan persiapan alat dan bahan

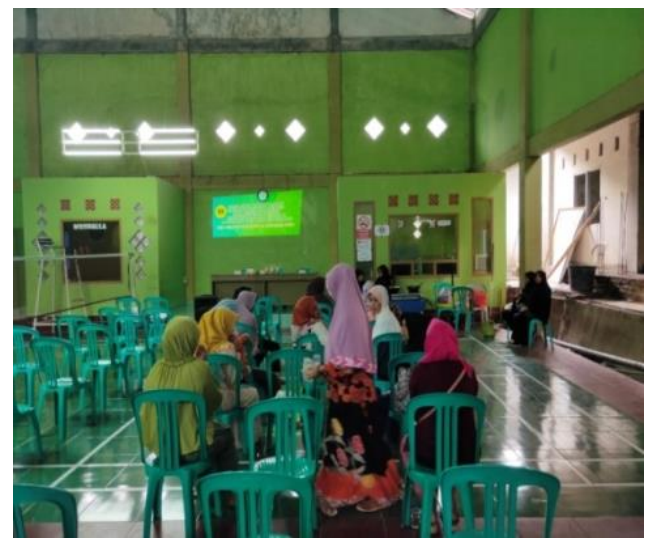

Gambar 3. Persiapan Program

Tahap kedua ialah persiapan bahan-bahan yang disediakan dalam proses pelatihan pembuatan stik ikan ialah: 1) daging ikan nila, 2) tepung beras (rose brand), 3) tepung tapioka, 4) blueband, 5) bawang putih, 6) lada bubuk, 7) penyedap rasa, 8) garam, 9) gula, 10) minyak, dan 11) terdapat bahan tambahan berupa daun seledri.

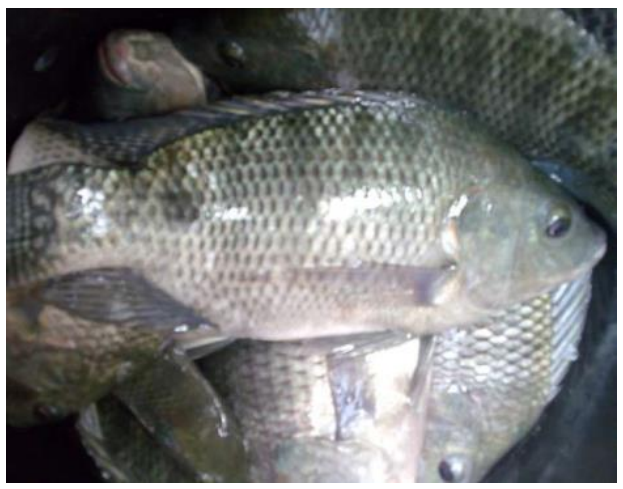

Gambar 4. Ikan nila sebagai bahan utama 


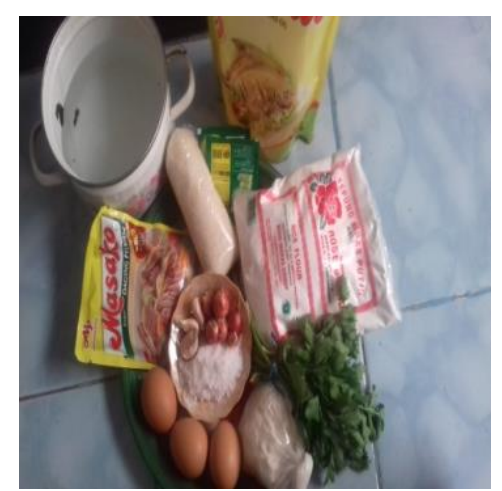

Gambar 5. Bahan stik ikan

Tahap ketiga pada kegiatan ini adalah pembukaan pelatihan. Pelatihan ini menghadirkan beberapa pihak diantaranya adalah kepala desa, ketua BUMDes, ketua dan ibu-ibu PKK, dan beberapa kadus dari masing-masing dusun desa Pringgajurang.

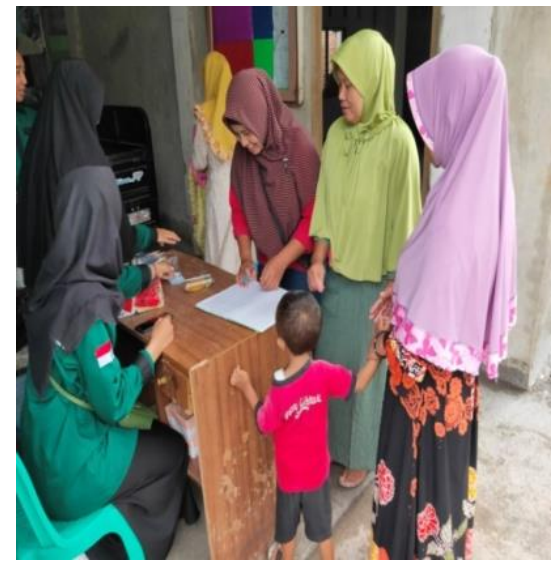

Gambar 6. Registrasi Peserta Sosialisasi

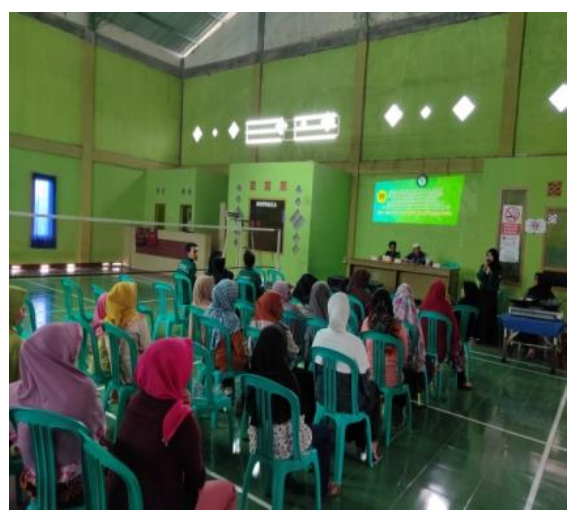

Gambar 7. Pembukaan Pelatihan

Pelatihan pembuatan stik ikan diawali dengan menyampaikan materi pengantar oleh pemateri. Dilanjutkan dengan praktik langsung yang melibatkan seluruh peserta pelatihan. 


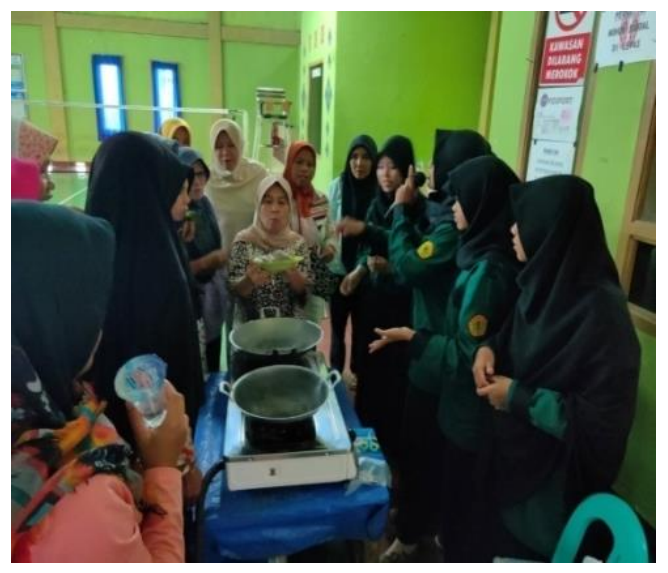

Gambar 8. Proses pembuatan stik ikan

Hasil pelatihan ini adalah produk stik ikan dengan tekstur renyah, lezat yang sedap dengan kualitas yang tidak kalah dengan hasil pabrik stik ikan besar lainnya. stik ikan yang sudah siap kemudian dicampurkan dengan bumbu yang terdiri atas 4 varian rasa yaitu bumbu rasa sambal balado pedas manis, rasa keju, rasa jagung bakar dan rasa sapi panggang (Barbeque). Kemudian dilakukan pengemasan kedalam plastik yang sudah disiapkan dengan berat masing-masing $100 \mathrm{gr}$, dan ditempelkan stiker yang memuat informasi produk. Selanjutnya dilanjutkan dengan bimbingan manajemen pemasaran disampaikan oleh pemateri. Adapun manajemen Pemasaran yang digunakan ialah secara langsung dan tidak langsung. Manajemen pemasaran secara langsung yakni memperomosikan produk olahan stik ikan kepada masyarakat disekitar secara langsung sedangkan manajemen pemasaran tidak langsung yakni melalui media sosial seperti WhatsApp, Facebook dan instragram.

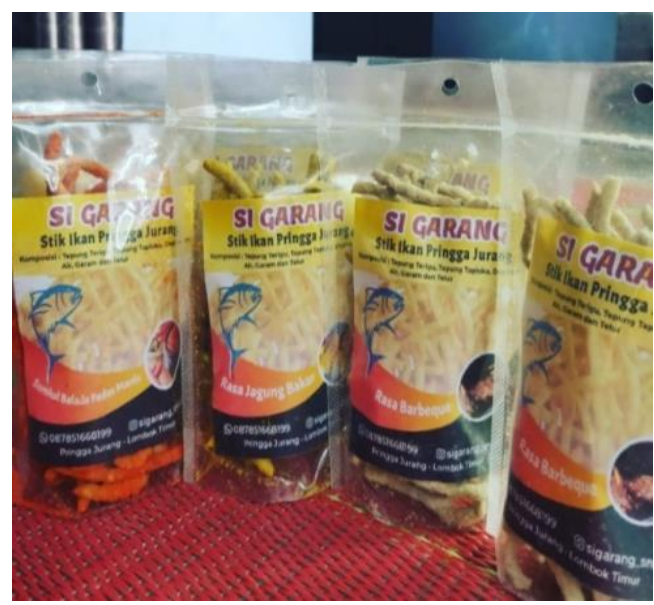

Gambar 9. Stik ikan yang sudah dikemas 


\section{KESIMPULAN}

Kesimpulan dari program pelatihan pembuatan stik ikan ini berguna untuk meningkatkan kualitas SDM yang mampu mengolah sumber daya alam yang merupakan potensi desa sehingga dapat meningkatkan taraf hidup masyarakat khususnya masyarakat didesa Pringgajurang. Berdasarkan pelatihan yang telah dilakukan diharapakan memberi nilai tambah yang baik sehingga pengoperasian pengolahan ikan dapat segera terlaksana dan bermanfaat bagi seluruh masyarakat desa Pringgajurang..

\section{UCAPAN TERIMA KASIH}

Terimakasih penulis ucapkan kepada semua pihak yang turut menyumbangkan keringat dan ide dalam kegiatan yang telah diselenggarakan oleh mahasiswa KKN Universitas Mataram periode 2019/2020, secara khusus kami sampaikan terimakasih sebesar-besarnya kepada:

1. Bapak kepala desa Pringgjurang, yang telah turut membantu dalam mengkoordir masyarakat desa untuk terlibat dalam acara yang kami selenggarakan ini,

2. Pengurus BUMDes Al-ikhlas yang telah membantu dalam membantu mengumpulkan tenaga kerja potensial yang siap untuk dilatih,

3. Peserta pelatihan pembuatan stik ikan yang bersedia hadir kelokasi pelatihan,

4. Secara umum kami ucapkan terimkasih kepada semua masyarakat yang turut membantu mensukseskan acara tersebut..

\section{REFERENSI}

Irmansyah, J dan Kusnadi. 2009. Sifat Listrik Telur Ayam Kampung Selama Penyimpanan. Jurnal Media Peternakan. 32 (1) : 22-30.

Muzakki. I. (2015). Manajemen Proses Produksi Stik ikan Lemuru (Sardinella lemuru) di Balai hasil pengolahan Perikanan dan Kelautan (BHPPK) Pelabuhan Perikanan Nusantara Prigi, Kabupaten Trenggalek, Jawa Timur. Surabaya. Fakultas Perikanan dan Kelautan Universitas Airlangga.

Pangabean, S. M. 2004. Manajemen Sumber Daya Manusia. Bogor: Ghalia Indonesia.

Pratiwi, Fitriana. 2013. Pemanfaatan Tepung Daging Ikan Layang Untuk Pembuatan Stik Ikan. Skripsi: Jurusan Teknologi Jasa Dan Produksi , Fakultas Teknik, Universitas Negeri Semarang.

Putri, D. A, Pratiwi, A, dan Suwartiningsih, N. 2018. Pemberdayaan Kelompok Wanita Tani dalam Diversifikasi Olahan Ikan Nila. Jurnal Pemberdayaan: Publikasi Hasil Pengabdian Kepada Masyarakat . 2 (2): 375 380.

Salaman, Y, Novita, S,dan Shaliha, N. R. 2015. Pengaruh Proporsi Daging Ikan Patin (Pangasius hypophtalmus) dan Wortel (Daucus carota L) Terhadap Kadar Protein, Kalsium DAN Daya Terima Stik Nuget Ikan. Jurkessia. V (3):51-58.

Siswanti, Agnesia, P. Y, dan A Katri, R. B. 2017. Pemanfaatan Daging dan Tulang Ikan Kembung (Rastrelliger kangurta) dalam Pembuatan Cemilan Stik. Jurnal Teknologi Hasil Pertanian. X (1): 41-49.

Utami, D. C. 2018. Pemberdayaan Perempuan Pesisir Melalui Pengembangan dan Pengauatan Perekonomian Berbasis Komoditas Lokal. Jurnal Soeropati. 1(1): 11-22.

Widiastuti, C. T., dan Niati, A. 2018. Pelatihan Pembuatan Stik Sehat Ikan Kakap untuk Pemberdayaanlbu Rumah Tangga Kelurahan Mlatiharjo Semarang. Jurnal Pengabdian Kepada Masyarakat. 9(2): 240247.

Yanuar, V, Suharjo, M, dan Igas, A. 2016. Pengaruh Bahan Baku Ikan Terhadap Nilai Organoleptik dan Nilai Kandungan Gizi Produk Stik Ikan Dikabupaten Kota Waringin Barat. Jurnal Ziraa'ah. 41 (3): 346-354. 